\title{
The Assessment of Companies and Organizations That Have Outstanding Results in the Field of Sustainability
}

\author{
By Carmen Valentina Radulescu ${ }^{1}$, Raluca Georgiana Ladaru ${ }^{1}$, Iulian Gole ${ }^{1}$, Carol \\ Cristina Gombos ${ }^{1}$
}

\begin{abstract}
Some multinational companies have obtained great results in the field of environmental protection, their business model being worldwide recognised. There is a permanent concern to promote sustainable policies, their efforts being unanimously appreciated. We will start our analysis from the results of an international survey, assuming that in order to develop a strategy to increase the efficiency of communication in the field of environmental protection we should establish what the ingredients of a successful recipe are, in terms of sustainability. In this paper we will also analyse the views of experts on companies that are considered being able to integrate sustainable development into their business strategy, as well as on NGOs that contribute most to positive advancement of the sustainability agenda. We will see that some companies or organizations are perceived as being leaders of these rankings, years in row, but there are also newcomers, a sign that there is a constant focus on this goal.
\end{abstract}

Keywords: environment protection, sustainability, multinational companies, survey

\section{Introduction and Research Background}

Generally, it is considered that the best organisations achieve best results by approaching environmental issue (Purvis \& all, 2019), quality of life (Whelan \& Fink, 2016), the care for global resources (Cretu, 2016). Transnational companies are facing two main challenges: to manage multicultural project teams (Bodislav et al., 2020) and to uphold collaboration using global technologies (Lasrado, 2018). Responsibility and good practices are the pillars of sustainability (UNCTAD, 2019). The companies that will embedded into their and business plans and strategies (Profiroiu et al., 2020), will create new sources of innovation (Sarbu et al., 2021), will make the employees excited (Radulescu et al., 2021) and stakeholders loyal (Crowther $\&$ all, 2018). The objective of this research is to understand which the best actors in this area are. To make a relevant analysis, we selected, as a starting point for the research, the survey conducted by GlobeScanSustainAbility Leaders Survey in 2019. We consider that an independent analysis of the results of this study is necessary because on the one hand it is one of the most prestigious research institutions and on the other hand because the basis of this analysis is the opinions of over 800 experts from the business environment, government, NGOs as well as academia, from 78 countries on different continents, who were asked to assess the progress made by various institutions since the Earth Summit from 1992 to 2019, in terms of sustainable development (Bran et al., 2020).

In this paper we will also analyse the views of experts on companies that are considered 
to be able to integrate sustainable development into their business strategy, as well as what are the NGOs that contribute most to positive advancement of the sustainable development agenda.

The idea to start our analysis from the results of the survey The 2019 GlobeScanSustainAbility Leaders Survey starts from the conviction that in order to develop a strategy to increase the efficiency of communication in the field of environmental protection we should see what the ingredients of a successful recipe are, in terms of sustainability, applied with appreciable results by different international companies. We will see that some companies or organizations are on top years in a row, so, in same cases, there is a permanent willing to promote sustainable policies, their efforts being unanimously recognized. There are also newcomers to these rankings, a sign that there is a constant focus on this goal.

\section{Methods}

Regarding the methodology of creating the questionnaire, the entire research was based exclusively on perception assessment of different specialists, working in the field of sustainability and sustainable development, people with a recognized level of expertise accumulated over several years, who come from different areas of activity but also from different geographical areas. That is why we consider that this questionnaire is one of the most representatives in the field and can be used successfully as a starting point for our further analysis in order to find effective ways to communicate in the field of environmental protection.

Thus, regarding their origin from the different sectors of activity, the respondents come from the following areas:

Table 1: Origin of respondents

\begin{tabular}{|c|c|c|c|c|c|c|}
\hline Areas & Guvernment sectors & Academic and reserach & NGO & Media & Corporate & Others \\
\hline Representativity & $5 \%$ & $16 \%$ & $16 \%$ & $21 \%$ & $36 \%$ & $6 \%$ \\
\hline
\end{tabular}

Source: data from the GlobeScan report

For a better representativeness and veracity of the obtained data, the opinion of different experts from different geographical areas, from all continents was used.

Table 2: Geographical origin of experts

\begin{tabular}{|c|c|c|c|c|c|}
\hline $\begin{array}{c}\text { Geogrphical } \\
\text { areas }\end{array}$ & $\begin{array}{c}\text { Africa and the } \\
\text { Middle East }\end{array}$ & $\begin{array}{c}\text { Latin } \\
\text { America }\end{array}$ & Asia-Pacific & $\begin{array}{c}\text { North } \\
\text { America }\end{array}$ & Europa \\
\hline Percentaje & $9 \%$ & $14 \%$ & $21 \%$ & $25 \%$ & $31 \%$ \\
\hline
\end{tabular}

Source: data from the GlobeScan report.

As we can see, there is a weighted participation so that the final results can have a very good margin of confidence. There is a higher share of European respondents but even this possible bias is reflecting the reality since Europe is the continent who decided to invest more, financially but institutionally, in sustainability and environment protection. Regarding the duration of the experience in years of the respondents, it was taken into 
account that this aspect should be somewhat balanced, however, larger share is held by people that worked more than 10 years in the area of sustainability and/or environment protection.

Table 3: Years of familiarity with the subject.

\begin{tabular}{|c|c|c|c|}
\hline $\begin{array}{c}\text { Duration of experience } \\
\text { in the field }\end{array}$ & $\begin{array}{c}\text { More than } \\
10 \text { years }\end{array}$ & $\begin{array}{c}\text { Between } \\
5 \text { and } 10 \text { years }\end{array}$ & $\begin{array}{c}\text { Between } \\
3 \text { and } 4 \text { years }\end{array}$ \\
\hline Weight & $67 \%$ & $23 \%$ & $10 \%$ \\
\hline
\end{tabular}

Source: data from the GlobeScan report.

\section{Results}

In the next part we will present the main data obtained regarding the involvement of different non-governmental, governmental and international entities

The performance of NGOs in contributing to the progress of sustainable development is positively assessed by most respondents. United Nations contribution is usually considered as being excellent by almost half of the experts. At the same time, very few experts appreciate the performance of national governments; institutional investors are also perceived as being among the low positive contributors.

Regarding the question of how they appreciate the performance of different organisations in terms of their contribution to the progress of sustainable development, starting from the 1992 Earth Summit in Rio, respondents had the following views.

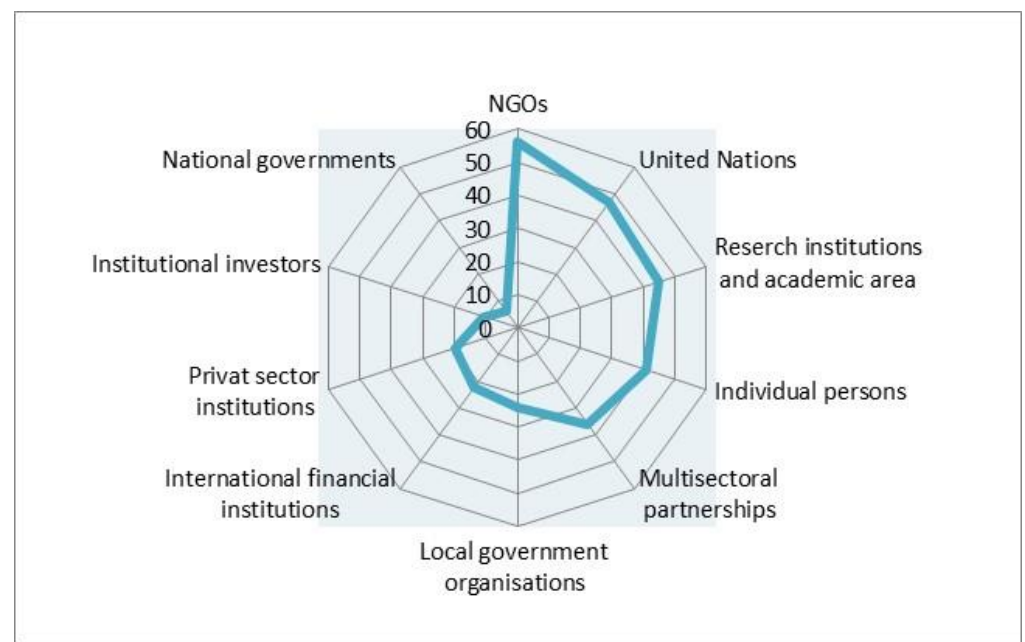

Picture no. 1. The situation the expert positive perception regarding the real contribution of the different entities in sustainable development area (\% of the answers that appreciated as very good their contribution).

Source: own representation from the data obtained in the GlobeScan report.

It is obvious that non-governmental organizations and the UN are perceived as true leaders in terms of their work for sustainable development and their performance is considered excellent by $56 \%$ and $47 \%$ of survey respondents. At the top, however, we can find also the research and academic institutes, but also individuals who have become 
known for their struggle for the environment protection. At the opposite pole are institutional investors and national governments that are perceived as having positive contributions of only $11 \%$ and $6 \%$ of the 807 survey participants, respectively.

It is also desirable to test if those who are perceived as being less appreciated in the first questions are in the first positions when we talk about negative perception of their activities. Consequently, in order to double check we have to look at the second picture. The graph appears almost in the mirror when we analyse the negative perception of the respondents. Again, national governments and institutional investors are seen as real brakes on sustainable development.

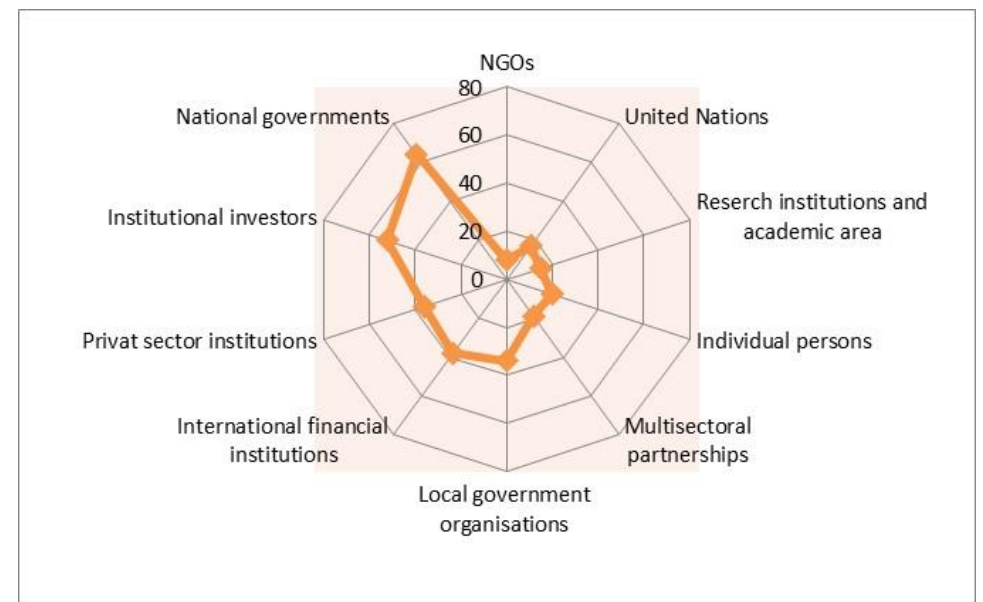

Picture no. 2. The situation of the negative perception of the experts regarding the real contribution of the different actors in the fight for sustainable development (\% of the answers that appreciated as very low their contribution). Source: own representation from the data obtained in the GlobeScan report.

In the next lines we will look more into details of the questionnaire regarding the perception of non-governmental organizations, regarding sustainable development.

When asked what you think are the first 3 NGOs that have contributed substantially to the progress of sustainable development, we will find that the World Wildlife Fund and Greenpeace lead the way.

Table 4: Experts' perception regarding the activity of NGOs.

\begin{tabular}{|l|c|c|c|}
\hline NGO & 2017 & 2018 & 2019 \\
\hline World Wildlife Fund & 36 & 29 & 28 \\
\hline Greenpeace & 20 & 13 & 18 \\
\hline World Resources Institute & 7 & 8 & 7 \\
\hline Oxfam & 7 & 7 & 11 \\
\hline The Nature Conservancy & 7 & 5 & 4 \\
\hline Creres & 4 & 5 & 4 \\
\hline
\end{tabular}

Source: data from the GlobeScan report.

WWF holds a dominant position, being perceived as a leader both globally and regionally, while Greenpeace also has strong performance. The World Resources Institute ranks top 
in all regions except Africa / the Middle East, while The Nature Conservancy is seen as a top NGO in America. Still, in the last years, we can observe a certain decline of WWF since other small NGOs started to became also effective in their work so more visible and appreciated by experts.

The perception of experts is somewhat different, depending on the geographical region where they operate. However, the World Widelife Fund ranks first in all regions and Greenpeace in second place, except for North America.

In order to have an even deeper understanding of the results, respondents were also asked what specific value the leadership of various NGOs appreciates. We believe that this is very important in order to better understand the factors that might influence the positive perception of experts about the work of NGOs and therefore how other NGO leaders could transform their organizations to be part of the top.



Picture no. 3: Perception of leadership values of the most active NGOs in promoting sustainability Source: own representation from the data obtained in the GlobeScan report.

This chart allows us to observe the grouped responses of experts who answered the question of why they believe that certain NGOs stand out in promoting sustainable development. We can conclude that among the most appreciated qualities is the collaboration of all stakeholders, followed by activism, innovation and research, initiatives, communication, commitments. In the lowest area we find standards of leadership, environmental protection, human rights, focus on goals and adherence to sustainable development policies.

These last values are the most interesting because in order to improve the results of environmental protection and conservation, according to experts, people have to increase their efforts. We deduce from this that although there is interest, will and collaboration at the level of NGOs to save the planet, there is still a need for more effective communication and pragmatic actions, management standards but especially a focus on sustainability goals. Another perspective of the survey is to measure the perception of large corporations, leaders in previous years or new entries, in promoting the values of sustainability and 
sustainable development.

When asked which specific companies you think are leaders of integrating sustainability into their business strategy, respondents had to choose a maximum of 3 names. There is a certain continuity of values over the years, absolutely natural given that it is not possible to make spectacular qualitative leaps from one year to another. However, there is a certain evolution, depending on different arguments.

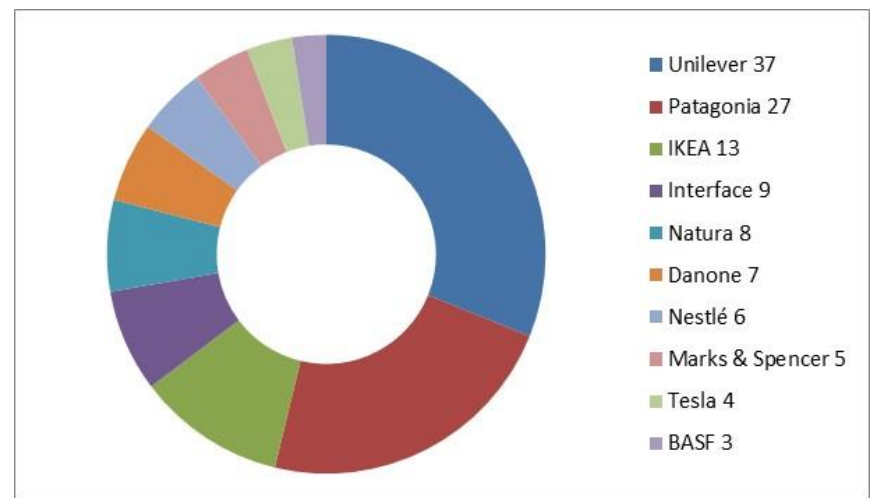

Picture no. 4. Ranking of the top 10 companies, perceived to be leaders in sustainable development.

Source: own representation from the data obtained from the GlobeScan report.

Unilever, Patagonia and IKEA again occupy the top three positions in the top ten. The vast majority of these companies are headquartered in Europe, with Nature being the only emerging company to appear on the list of top rated corporations. BASF regained its position in the top ten after falling off the list of leaders in 2018.

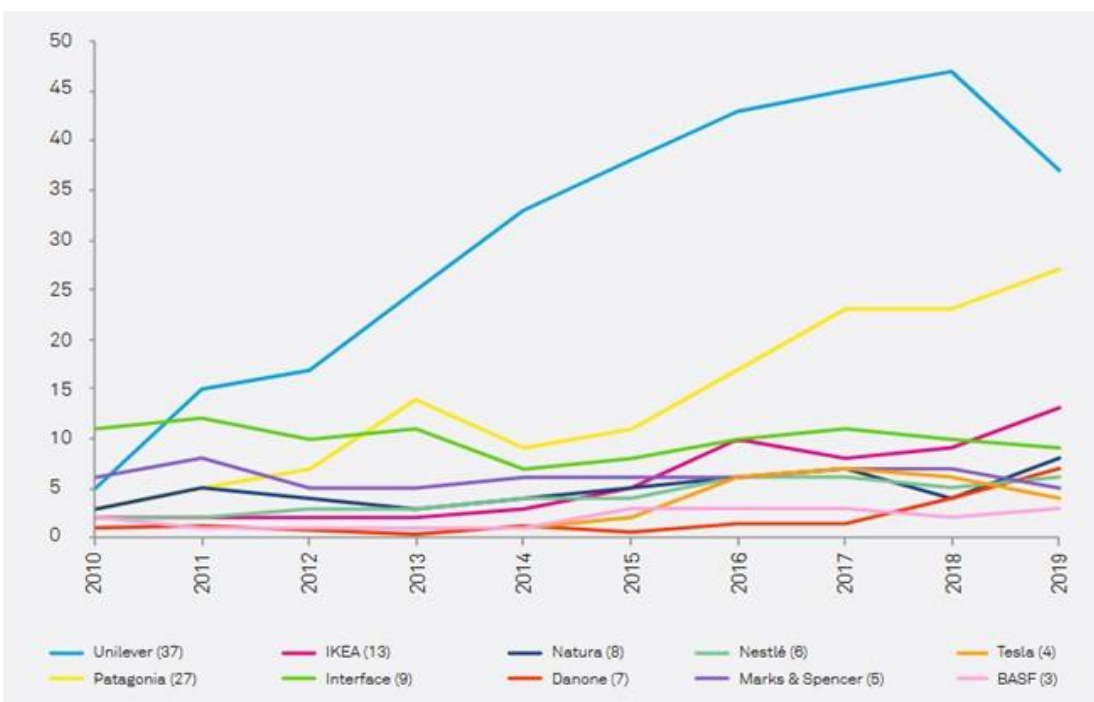

Picture no. 5: The evolution of the ranking of specialists' perception on the leading companies of sustainability, in the last 10 years.

Source: data from the GlobeScan report. 
If we analyse what has happened in the last 10 years, regarding the perception of these companies we will see that there are interesting evolutions. Thus, the degree to which experts perceive Patagonia as a leader in terms of sustainability is on the rise, while the rise of Unilever has fallen this year for the first time. The decline can be explained by the change of CEO in 2019, this survey measures the perception of experts and not necessarily accurate economic performance.

The values of recognizing the efforts of IKEA, Natura and Danone have also increased. Interface remains the most stable company from this point of view, in the last 10 years always being at least in the top 4 .

However, there are very big differences, at the geographical level, from the point of view of the specialists' perception. When experts were asked to identify companies that are headquartered and operate in their region, a multitude of companies were mentioned, which means that many companies gained visibility of sustainability leadership, due to their activities. Experts from Latin America and North America choose Nature and Patagonia in the number one positions, with a very large margin of difference.

However, there are some obvious differences in the overall ranking. For example, although Toyota or Aramex are leaders in their geographical areas, Asia and Africa, respectively, they are not perceived globally as part of the top 10. This means that although at the regional level there is some recognition of their efforts, at the global level, companies operating in Europe, North America and Latin America are much more active and therefore more appreciated. Another observation is that some companies are more popular in their geographical areas than globally (Walmart, Apple, Microsoft).

The experts believe that integrating the sustainability values into the DNA of the business model is the most important value that corporate management could develop. Offering sustainable products and services, a supply chain that respects the principles of sustainability, a direction of development of the management of the different industries branches is also perceived as very important.

As in the case of NGOs, communication, reporting, transparency are among the least appreciated values; that is why we believe that an extension of the analysis could bring new ideas on how these performances could be improved, with the ultimate goal of better environmental protection.

In the following we will make a detailed analysis of the performances of the companies in the top of the GlobeScan questionnaire. For this we will call on the public sources of these companies, activity reports or CSR. The final goal is to really compare the declared performances, in order to be able to finally see what the differences between the perception of the specialists and the concrete public data are.

In order to make a reasonable comparison, we decided to have a closer look only to three companies from top 10, which have a similar business model with product from same area. We decided to analyse the performance of Unilever, Danone and Nestlè (for the moment we consider a bit complicated to compare hi-tech, furniture, fashion or medical companies with those specialised in food products).

In order to have a clear understanding we decided to take data from official sources from all three companies regarding their performances in the area of environment protection. Of course, each company has its own way of reporting and a different baseline but we will focus on the last three years. For the unavailable data we did an approximation. We decided 
to classify the indicators in five main files: water consumption, GHG, energy from renewable sources, wasted, sustainable sources of raw materials. The collection of data seemed to be the most challenging part, since each company has a different style of communication and not all data are available, or at least not easy to find.

Table 5: The main data obtained regarding the environmental performance of the 3 companies

Unilever

\begin{tabular}{|c|c|c|c|c|c|}
\hline Year & $\begin{array}{c}\text { Water(diminishing of } \\
\text { water consumption) }\end{array}$ & $\begin{array}{c}\text { Reduction of } \\
\text { greenhouse gas } \\
\text { emission }\end{array}$ & $\begin{array}{c}\text { Energy (from } \\
\text { renewable } \\
\text { sources) }\end{array}$ & $\begin{array}{c}\text { Waste } \\
\text { associated } \\
\text { with products }\end{array}$ & $\begin{array}{c}\text { Sustainable } \\
\text { sources of raw } \\
\text { materials }\end{array}$ \\
\hline 2017 & $2,0 \%$ & $9,0 \%$ & $33,6 \%$ & $29,0 \%$ & $56,0 \%$ \\
\hline 2018 & $2,0 \%$ & $6,0 \%$ & $36,7 \%$ & $31,0 \%$ & $56,0 \%$ \\
\hline 2019 & $-1,0 \%$ & $2,0 \%$ & $45,8 \%$ & $32,0 \%$ & $62,0 \%$ \\
\hline
\end{tabular}

\section{Danone}

\begin{tabular}{|c|c|c|c|c|c|}
\hline Year & $\begin{array}{c}\text { Water(diminishing of } \\
\text { water consumption) }\end{array}$ & $\begin{array}{c}\text { Reduction of } \\
\text { greenhouse gas } \\
\text { emission }\end{array}$ & $\begin{array}{c}\text { Energy (from } \\
\text { renewable } \\
\text { sources) }\end{array}$ & $\begin{array}{c}\text { Waste } \\
\text { associated } \\
\text { with products }\end{array}$ & $\begin{array}{c}\text { Sustainable } \\
\text { sources of raw } \\
\text { materials }\end{array}$ \\
\hline 2017 & $1,0 \%$ & $13,2 \%$ & $13,2 \%$ & $10,0 \%$ & $36,0 \%$ \\
\hline 2018 & $1,0 \%$ & $15,6 \%$ & $16,2 \%$ & $13,0 \%$ & $43,0 \%$ \\
\hline 2019 & $-1,0 \%$ & $24,8 \%$ & $19,7 \%$ & $19,0 \%$ & $81,0 \%$ \\
\hline
\end{tabular}

Nestlé
\begin{tabular}{|c|c|c|c|c|c|}
\hline Year & $\begin{array}{c}\text { Water(diminishing of } \\
\text { water consumption) }\end{array}$ & $\begin{array}{c}\text { Reduction of } \\
\text { greenhouse gas } \\
\text { emission }\end{array}$ & $\begin{array}{c}\text { Energy (from } \\
\text { renewable } \\
\text { sources) }\end{array}$ & $\begin{array}{c}\text { Waste } \\
\text { associated } \\
\text { with products }\end{array}$ & $\begin{array}{c}\text { Sustainable } \\
\text { sources of raw } \\
\text { materials }\end{array}$ \\
\hline 2017 & $2,5 \%$ & $3,7 \%$ & $19,5 \%$ & $34,2 \%$ & $74,0 \%$ \\
\hline 2018 & $3,1 \%$ & $6,0 \%$ & $21,2 \%$ & $48,3 \%$ & $81,9 \%$ \\
\hline 2019 & $3,9 \%$ & $1,4 \%$ & $23,0 \%$ & $58,4 \%$ & $86,0 \%$ \\
\hline
\end{tabular}

Sources: companies'publications

When we look into details to the data we can remark that Unilever is an absolute leader, in term of performance, concerning the energy used from renewable sources, while to all the other criteria is on the second position. Danone is first on reduction of GHG emission, while Nestlé is number one in water consumption, waste and raw materials from sustainable sources.

Let's assume that each indicator (water, GHG, energy, waste and raw materials) has an equal weight of $20 \%$ in a general equation of a new index, which could give an unbiased idea about the companies' advancement.

$I=0,2 * W c+0,2 * G H G+0,2 * E r+0.2 * W p+0.2 * R m$

Where

I is the proposed index, Wc - water consumption, GHG - greenhouse gas emissions, Er energy renewable, $\mathrm{Wp}$ - waste associated with products, $\mathrm{Rm}$ - raw materials. After calculations the results are: 
Table nr. 6. Evolution of the Index.

\begin{tabular}{|c|c|c|c|}
\hline & Unilever & Danone & Nestlé \\
\hline 2017 & 0,2592 & 0,1468 & 0,2677 \\
\hline 2018 & 0,2634 & 0,1776 & 0,32102 \\
\hline 2019 & 0,2816 & 0,287 & 0,34546 \\
\hline
\end{tabular}

Sources: own calculations

From a graphical representation we can see that, based on the reported results and calculation, Nestlé had the best performance, followed by Unilever and Danone. All companies registered a continuing positive evolution regarding the protection of environment, during the last 3 years. Unilever had a steady progress while Danone had a consistent progress in 2019.

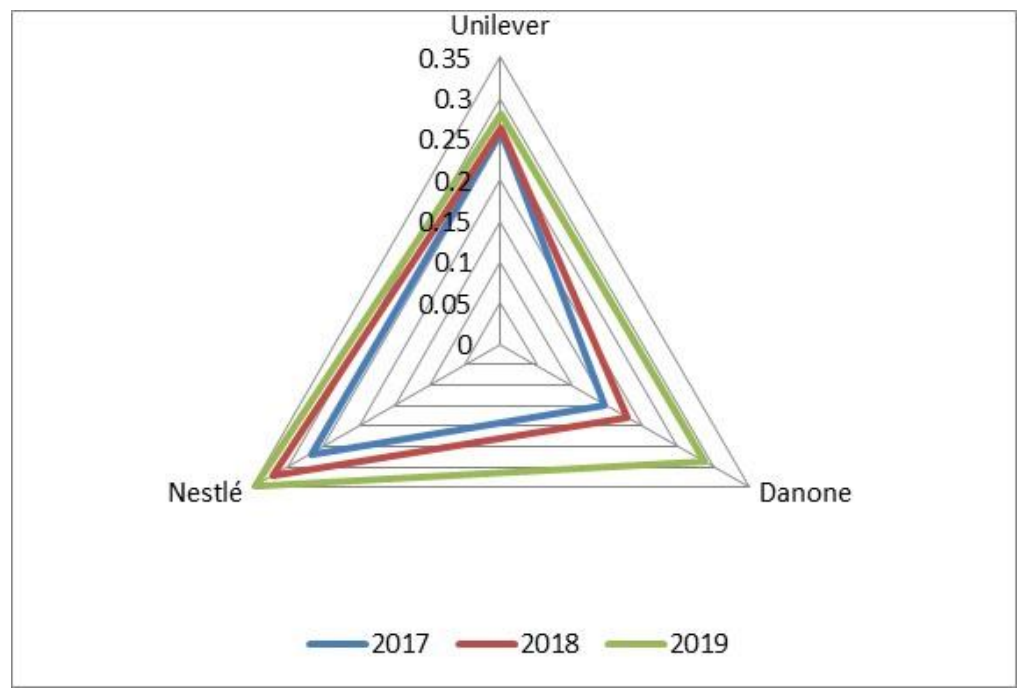

Picture no. 6. Graphical representation of companies environment performances.

Source: own representation

If we look closer and compare these results with the perception of specialists measured by GlobeScan we can see that the advance of Unilever is not that clear. Of course, someone could argue that the concise style of presentation, the easiness access to archives and data, the trustiness of reporting and even the milestones they have, are making from them a real number one, despite concrete data. One way or another, Danone and Nestlè are doing a great job, and are closer to leader, year after year.

\section{Conclusions}

The 2019 survey shows a slightly more balanced assessment of the corporate landscape compared to previous years. While Unilever's supremacy is maintained for the eighth consecutive year in this ranking, other companies have gained ground.

Unilever remains in number one position, being nominated from $37 \%$ of the 800 expert respondents; however, his ranking fell by 10 points compared to 2018. At the same time, 
IKEA, Patagonia, Natura, Danone and Nestlé have intensified their ambition to have a greater impact in the field of sustainability and sustainable development.

The 2019 survey reveals that the integration of sustainability values and even the transformation of sustainability into the core business model are the key features recognized by expert respondents as defining for corporate management. The private sector, institutional investors and national governments are identified by experts as having the weakest contribution to global sustainable development. In contrast, experts believe that some NGOs contribute greatly to the transition to sustainable development and point to WWF, Greenpeace, WRI, Oxfam and Nature Conservancy as leaders in the rankings. Maybe just measuring the perception is not enough since the marketing techniques and popularity could influence even the specialist minds, therefore it would be interesting to have a single and clear way of communication, with the same baseline, with the same structure of reports, in the same style. If all companies would do that, then the creation of a specific weighted indicator that could englobe all the fifth areas could be useful and effective in an unbiased assessment of the entire performances regarding the environment protection and sustainability.

\section{References}

Bodislav, D. A., Buzoianu, O. A. C., Burlacu, S., \& Rădulescu, C. V. (2020). Analysis of companies in Romania from the perspective of risk perception and the management needs thereof. Economic Convergence in European Union, 341.

Bran, F., Rădulescu, C. V., Bodislav, D. A., \& Burlacu, S. (2020). Environmental risks in the context of globalization. Economic Convergence in European Union, 350.

Carbon Disclosure Project, 2020, CarbCDPon Disclosure Project - The A List 2020. Retrieved from https://www.cdp.net/en/cities-discloser

Cretu, R.F., Reflection of the environmental aspects onto economic and financial indicators within responsable companies, Supplement of "Quality-access to success" Journal Vol. 17, S1, 2016, pp. 279-284, ISSN 1582-2559. Retrieved from http://www.srac.ro/calitatea/arhiva/supliment/2016/QasContents Vol.17 S1 March-2016.pdf.

Crowther, D.,Seifi, S. \& Wond, T., 2018, Responsibility and Governance: The Twin Pillars of Sustainability (Approaches to Global Sustainability, Springer, ISSN 2520-8772, ISBN 978-981-13-1046-1.

Danone, 2019. Exhaustive 2019 environmental data. Retrieved from https://www.danone.com/content/dam/danone-corp/danone-com/rai/2019/pdf/goal6/danone-exhaustive-environmental-2019-data.pdf

Danone, 2019. Preserve and renew the planet's resources. Retrieved from https://www.danone.com/integrated-annual-reports/integrated-annual-report2019/performance/preserve-and-renew-the-planet-s-resources.html

Globescan, 2019, The 2019 GlobeScan SustainAbility Leaders Survey Report. Retrieved from https://globescan.com/2019-sustainability-leaders-report/

Lasrado, F. 2018, Achieving Organizational Excellence: A Quality Management Program for Culturally Diverse Organizations, Springer, ISSN 2192-8096, ISBN 978-0-319-70074-8.

Nestlè, 2020. Performance and reporting. Retrieved from https://www.nestle.com/sites/default/files/202103/creating-shared-value-report-2020-en.pdf

Profiroiu, C. M., Bodislav, D. A., Burlacu, S., \& Rădulescu, C. V. (2020). Challenges of Sustainable Urban Development in the Context of Population Growth. European Journal of Sustainable Development, 9(3), 51-51.

Profiroiu, M. C., Radulescu, C. V., Burlacu, S., \& Guțu, C. (2020). Changes and trends in the development of the world economy. In Competitivitatea şi inovarea în economia cunoaşterii (pp. 324-330).

Purvis, B., Mao, Y. \& Robinson, D. Three pillars of sustainability: in search of conceptual origins. Sustainability Science 14, 681-695 (2019). Retrieved from https://doi.org/10.1007/s11625-018-0627-5 
Radulescu, C.V.; Ladaru, G.-R.; Burlacu, S.; Constantin, F.; Ioanăș, C.; Petre, I.L. (2021) Impact of the COVID-19 Pandemic on the Romanian Labor Market. Sustainability 2021, 13, 271. https://doi.org/10.3390/su13010271

Sarbu, R., Alpopi, C., Burlacu, S., \& Diaconu, S. (2021). Sustainable urban development in the context of globalization and the health crisis caused by the covid-19 pandemic. Les Ulis: EDP Sciences. doi:http://dx.doi.org/10.1051/shsconf/20219201043

UNCTAD, 2019, Responsible and sustainable business practices and corporate social responsibility and enterprise development, Trade and Development Board Investment, Enterprise and Development Commission, Geneva, 17-19 June 2019 Item 3 of the provisional agenda. Retrieved from https://unctad.org/system/files/official-document/ciimem4d20 en.pdf

Unilever, 2019, Unilever Sustainable Living Plan: 3-year summary of progress 2017-2019. Retrieved from https://www.unilever.com/Images/uslp-3-year-performance-summary-2017-2019 tcm244$\underline{549781 \text { en.pdf }}$

Whelan, T., Fink, C. 2016, The Comprehensive Business Case for Sustainability, Harvard Business Review, Retrieved from https://hbr.org/2016/10/the-comprehensive-business-case-for-sustainability 